\title{
Koinoi Nomoi: Hadrian and the Harmonization of Local Laws*
}

\author{
Juan Manuel Cortés-Copete
}

For a number of years now, Aelius Aristides' Roman Oration has enjoyed a well-deserved reputation among historians of antiquity. ${ }^{1}$ However, this has not always been the case. Despite describing it as 'the best general picture of the Roman Empire in the second century, ${ }^{2}$ not even the prestige of the Russian scholar M. Rostovtzeff was sufficient to defend the Roman Oration from the disdain of his colleagues. The flowery prose of the Greek sophist seemed to most scholars at the time as pointless as it was ponderous, for which reason quotes from the Roman Oration were few and far between. This began to change from the 196os onwards, when it was discovered that the Second Sophistic was not only a worthy object of literary but also social study. This revival of literary studies at the end of the twentieth century heralded an awakened scholarly interest in Aristides' oration. ${ }^{3}$ An important factor for its historiographical renaissance has been the incorporation of 'narrative' as a category of historical analysis. For this reason, the Roman Oration is nowadays considered a magnum opus not only as regards ancient rhetoric but also with respect to the narrative construction of the Roman Empire, ${ }^{4}$ and should thus regain its rightful place as 'the best general picture of the Roman Empire in the second century'.

In the first decades of the second century, the Roman Empire had set out on the path towards the harmonisation of local and regional laws whose origins, in

* This article is part of the project 'Adriano y la integración de la diversidad regional' (HAR201565451-c2-1 MINECO/FEDER), financed by the Ministerio de Economía y Competititvidad, Government of Spain.

1 Excellent translation, accompanied by the Greek text, and commentary: Elio Aristide, A Roma (a cura di F. Fontanella) (Pisa 2007). I have used the English translation by C. Behr, P. Aelius Aristides, The Complete Works, II (Leiden 1981).

2 M. Rostovtzeff, The Social and Economic History of the Roman Empire (Oxford 1926), 125.

3 S. Swain, Hellenism and Empire (Oxford 1996), 254-297.

4 L. Pernot, 'Aelius Aristides and Rome' in W.V. Harris (ed.), Aelius Aristides between Greece, Rome and the Gods (Leiden 2008), 175-201; S.C. Jarratt, 'An imperial anti-sublime: Aristides' Roman Oration (or.26)' in L. Pernot, G. Abbamonte and M. Lamagna (eds.), Aelius Aristides écrivain (Turnhout 2016), 213-229. 
my judgement, can be found in the Emperor Hadrian's political and legal undertakings. The purpose of this paper is twofold. On the one hand, I will explore how this process of legal harmonization became a central phenomenon in the Aristides' narrative of the Roman Empire. On the other hand, I will propose the hypothesis that the legal and judicial reforms promoted by Hadrian in the Greek cities are the historical background of the Aristides' picture of Rome as an empire founded on Justice. ${ }^{5}$

\section{Common Laws}

Aristides arrived in Rome in the fullness of youth in AD142 or 143, all set to embark on a successful literary and political career. Although his hopes were dashed by ill health, he nevertheless had the opportunity to read the Roman Oration in public. ${ }^{6} \mathrm{He}$ had arrived in the Empire's capital barely four years after the death of Hadrian, to whom he owed the name Aelius and the urban development of his birthplace Mysia. 'The best of emperors' (Aristid. 23.73) was his political barometer.

Therefore, I would like to start this study of the legal harmonisation of the Empire under the auspices of Hadrian with a quote from the Roman Oration:

And now, indeed, there is no need to write a description of the world, nor to enumerate the laws of each people, but you have become universal geographers for all men by opening up all the gates of the inhabited world; and by giving to all who wish it the power to be observers of everything

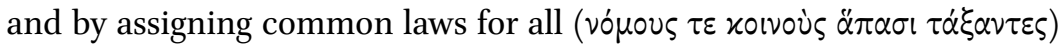
and by stopping practices which formerly were pleasant to read about, but were intolerable if one should actually consider them ...

Aristid. 26.102

In fewer than eight lines, Aristides paints an impressionist portrait of the Roman Empire, a picture imbued with his own personal experience. As noted, it should be remembered that the oration was read in Rome during the young sophist's Grand Tour of the Mediterranean, which gives new meaning to 'the open gates' of the world. Moreover, he intended to proclaim that one of the

5 K. Tuori, The Emperor of Law (Oxford 2016), 196-199.

6 L. Pernot, Éloges grecs de Rome (Paris 2004), 19-21, 163-170, with references to previous debates; Pernot 2008, op. cit. (n. 4), 176. 
oldest literary genres of Greek culture, the geographical and ethnographical narrative whose model derived from Herodotus, had finally been surmounted. The 'Father of History' had defined a method for fulfilling his historiographical purpose, since his idea was to 'move forward in my account, describing alike the small and large cities of humankind.7 This unique itinerant method is what Aristides declared obsolete. With this announcement of the demise of the Periegesis as a literary genre, he also intended to sanction the end of Roman expansion, now that the Empire dominated the largest and best part of the ecumene. ${ }^{8}$

In these lines, however, Aristides also seems to refute Plutarch's opinion that had Alexander the Great not died so young, 'one law would govern all mankind

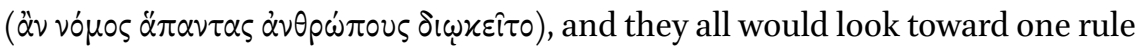

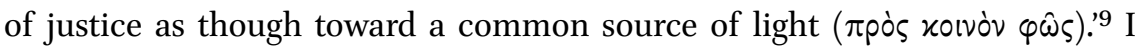
believe that it would not be farfetched to say that Aristides was familiar with this passage and that, in some way, he was challenging it. He claimed that the world had been immersed in chaos until the advent of Rome, a moment at which 'the confusion and faction ceased and there entered in universal order and a glorious light ( $\left.\varphi \hat{\omega} \varsigma \lambda \alpha \mu \pi \rho{ }^{\circ} v\right)$ in life and government and the laws came to the fore ( $\nu \dot{o}^{\mu} \mu \mathrm{ol} \tau \varepsilon \dot{\varepsilon} \xi \varepsilon \varphi \alpha^{\prime} \nu \eta \sigma \alpha \nu$ ) and the altars of the gods were believed in. ${ }^{10}$

The references to laws and light in life are clear evocations of the passage from Plutarch. In this way Aristides argued against the assertion that Alexander had already established a world order. The Roman Oration is based on a number of comparisons between the Roman Empire, the Greek hegemonies and past kingdoms which served to demonstrate the historical superiority of Rome. Alexander had never reigned over the territories that he had conquered. Alexandria was his only legacy which, however, 'he generously founded for you, so that you might possess and rule over the greatest city after your own.' Aristides had declared, 'What laws did he institute for each people?'11 'None' was the obvious reply. The legal unification of the world was thanks to Rome, rather than to the conqueror's unfinished work.

Hdt. 1.5.3. K. Karttunen, 'Phoebo vicinus Padaeus: reflections on the impact of Herodotean ethnography', in J. Pigon (ed.), The Children of Herodotus. Greek and Roman Historiography and Related Genres (Newcastle 2009), 17-25; J.E. Skinner, The Invention of Greek Ethnography (Oxford 2012).

8 Aristid. 26.28, 70, 99 .

$9 \quad$ Plut. De Alexandri Fortuna aut Virtute 33od. C.P. Jones, Plutarch and Rome (Oxford 1972), 68: 'Plutarch has drawn on the same stock of themes as Aristides, but his purpose is entirely different.'

$10 \quad$ Aristid. 26.103.

11 Aristid. 26.26. Fontanella 2007, op. cit. (n. 1), 95-96. 
The trumpeted demise of that ethnography focusing on the analysis of the laws of each nation as a means of better understanding local customs had its particular echo at schools of rhetoric. At the end of the third century, Menander Rhetor recognised the futility of addressing the topic of laws in praise of cities, insofar as all of them were governed by 'the common laws of the Romans'.

Nowadays, however, the topic of laws is of no use, since we conduct pub-

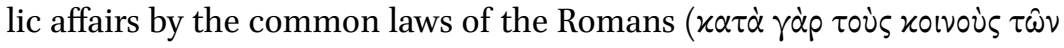

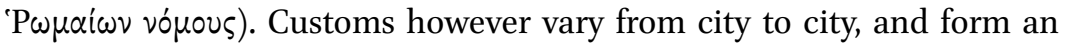
appropriate basis of encomium.

Men. Rh. I 363, ll. 11-14 12

M. Talamanca can be credited with having introduced this passage in the debate on the effects of the Constitutio Antoniniana. ${ }^{13}$ Since the end of the nineteenth century, it has been claimed that the universal grant of Roman citizenship had put an end to the multiplicity of local and regional public and private rights which had survived since the times of the conquest and which were then replaced with Roman laws. ${ }^{14}$ In this passage, Talamanca held, it was possible to glimpse the real confirmation of this thesis. Recognising the absurdness of resorting to the topic of local laws to praise a city was tantamount to ratifying its obsolescence. For this reason, 'the topic of laws is of no use, since we conduct public affairs by the common laws of the Romans.'

In contrast to the hypothesis that local laws ceased to exist after AD 212, there are those who, through the study of specific documents, have been able to show that different legal systems and traditions were still in place in the provinces and cities of the Empire after the proclamation of the Constitutio Antoniniana. ${ }^{15}$ The strongest evidence against the thesis of the end of the multiplicity

12 English translation: D.A. Russell and N.G. Wilson, Menander Rhetor, edited with a translation and commentary (Oxford 1981).

13 M. Talamanca, 'Su alcuni passi di Menandro di Laodicea relativi agli effetti della Constitutio Antoniniana', Studi in onore di E. Volterra V (Milano 1971), 433-56o.

14 L. Mitteis, Reichsrecht und Volksrecht in den östlichen Provinzen des römischen Kaiserreichs (Leipzig 1891); P. Garnsey, 'Roman citizenship and Roman law in the Late Empire', in S. Swain and M. Edwards (eds.), Approaching Late Antiquity (Oxford 2006), 133-155. The broad historiographical debate is summarised, with references, in V. Marotta, La cittadinanza romana in età imperiale (Torino 2009), 133-164, and more recently in G. Kantor, 'Local law in Asia Minor after the Constitutio Antoniniana', in C. Ando (ed.), Citizenship and Empire in Europe 200-1900 (Stuttgart 2016), 45-62.

15 J. Modrzejewski, 'Ménandre de Laodicée et l'édit de Caracalla', in Symposion 1977: Vorträge zur griechischen und hellenistischen Rechtsgeschichte (Cologne 1982), 335-363. 
of local rights in AD 212 can be found in the letter of Gordian III to Epaphras, a citizen of Aphrodisias. In it, the Emperor, some thirty years after the proclamation, promised the local aristocracy to preserve and protect $\tau \hat{\omega} \nu \tau \hat{\jmath} \varsigma \pi \alpha \tau \operatorname{li}^{\prime} \delta \circ$

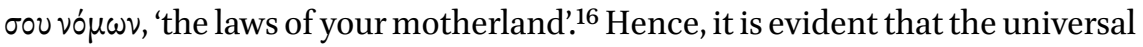
grant of Roman citizenship did not imply the immediate replacement of local legal systems which, subject to a long and complex process of harmonisation and substitution, continued to be effective.

To this debate should be added two well-known but barely appreciated arguments. The first is obvious. Menander Rhetor does not mention the Constitutio Antoniniana anywhere in his work. ${ }^{17}$ This omission could, of course, be due to the fact that there was no need to mention the universal grant of Roman citizenship by Caracalla in a treatise on epideictic rhetoric. However, as a literary precedent for the Menander's statement about the common laws of the Romans, the cited passage from Aristides - and this is the second argumentmay rekindle doubts about the existence of a cause-effect relationship between the Constitutio Antoniniana and Menander's text. Menander did not need the universal grant of Roman citizenship to write those lines about common laws: he could simply have been inspired by what Aristides wrote a century earlier.

I believe that it can be said that, in this regard too, Menander drew directly from Aristides' Roman Oration. The author of the epideictic treatise was familiar with the second-century sophist's oeuvre and used it as a model and benchmark for many of his opinions. As a matter of fact, Menander cites Aristides' Romaikos logos as one of the sources for composing the praise of the cities and, particularly, for the topic of constitutional rule. ${ }^{18}$ In the absence of prior evidence, the phrase hoi koinoi nomoi could thus be understood as a rhetorical innovation of Aristides, borrowed by Menander. With this expression, the intention of the Mysian sophist would have been to rebut the arguments of those who attributed to Alexander the idea of introducing a sole legal system for the whole ecumene. Rome's common laws were superior over what Alexander accomplished in his unifying project, for both their variety and because of their status as 'common', viz. shared by all..$^{19}$ To my mind, it is possible to hold that Menander's claim regarding the governing of public affairs by the common laws of the Romans was directly inspired by the Roman Oration, one of

16 J. Reynolds, Aphrodisias and Rome (London 1982), no. 22; Kantor 2016, op. cit. (n. 14), 4749 .

17 As indicated by Modrzejewski 1982, op. cit. (n. 15), 343 .

18 F. Gascó, 'Menander Rhetor and the works attributed to him', $A N R W$ II 34.4 (Berlin 1998), 3127. Men. Rh. I 36o, l. 5 .

19 Aristid. 23.64-65: a praise of 'the common', koinon, as political concept. 
the models that he admired most, where it had already been noted that Rome had established 'common laws for all'. But over and above any new meanings that the expression may have had in the third century, it is necessary to delve into the origin and essence of the words of Aristides. And by my reckoning, Aristides' statement about "common laws for all" was none other than a reflection of the legal and political reforms undertaken by Hadrian. I will now set out my arguments in this respect.

\section{$2 \quad$ Hadrian and City Laws}

The passage from Aristides under study here has not gone unnoticed by modern scholars who have either been inclined to glimpse in it a vague reference to the ius gentium or, in line with Bleicken, to the regulatory activity of the emperors. ${ }^{20}$ Indeed, it was the emperors who, through new forms of lawmaking, the constitutiones, were becoming the driving force behind legal integration. ${ }^{21}$ As I see it, the Emperor Hadrian was one of the prime movers in this process, ${ }^{22}$ not only because of his desire to maintain a constant presence in the provinces and their cities, which he favoured like no other emperor had done before, but also because he explicitly and practically expressed that the legal diversity of the Empire was an asset worthy of being preserved..$^{23}$ Nonetheless, the preservation of this legal diversity in the imperial context called for a process of legal harmonisation.

A good point of departure may be the Emperor's own comments on the Italicans, as transmitted by Aulus Gellius.

... and we think that colonies are of a better station than municipalities. About the delusions of this belief, which is so widespread, the deified Hadrian spoke most knowledgeably in the address he gave in the senate about the city of Italica (de Italicensibus) whence he has his own descent,

20 Departing from the seminal study conducted by J.H. Oliver, The Ruling Power (Philadelphia 1953), 959-980, although overly focused on collateral issues. V.J. Bleicken, 'Der Preis des Aelius Aristides auf das römische Weltreich', Nachrichten der Akademie der Wissenschaften in Göttingen. Philologisch-Historische Klasse 7 (1966), 243; Fontanella 2007, op. cit. (n. 1), 151.

21 J.-P. Coriat, Le prince législateur (Rome 1997), 8-11.

22 C. Ando, Imperial Ideology and Provincial Loyalty in the Roman Empire (Berkeley 2000), 319.

23 B. d'Orgeval, L'Empereur Hadrien, ouvre législative et administrative (Paris 1950), 193-200; A. D'Ors, 'La signification de l'ouvre d'Hadrien dans l'histoire du droit romain', in Les empereurs romains d'Espagne (Paris 1965), 147-161. 
and he revealed that he was amazed because both the citizens of Italica themselves, and likewise certain other long-established municipalities (municipia antiqua) amongst which he names Utica, although they could use their own customs and laws (cum suis moribus legibusque uti possent), were very eager to be changed to the juridical status of colony.

Gell. $N A$ 16.13.4. Translated by Boatwright

This extract has been used to discuss the nature of municipia and how that differed from the status of Roman colonies. ${ }^{24}$ What interests me about it here, however, are the principles on which Hadrian based his political action in the cities of the Empire. ${ }^{25}$ It is extremely interesting that he stressed that the right of the municipia to use their own laws and customs, suis moribus legibusque uti, was a thing of great value that the Empire should cherish. His amazement ${ }^{26}$ at the Italicans' pretensions to the status of a Roman colony was based on the fact that, for him, the particular legal and political systems of municipia were assets in themselves which should not be sniffed at or allowed to dwindle because of their desire to become colonies. Only if we accept this assumption as a principle of Hadrian's administration - the conviction that it was good that cities used their own laws - can we fully understand the far-reaching, systematic political and legal intervention in the cities of the Empire. This political principle can be even more clearly seen in the Emperor's relationship with some Greek poleis.

Let us first take a look at a text that is as important as it is controversial due to the substantial deterioration that it has suffered over the centuries: the decree of Synnada published at Athens. Although Graindor, the first scholar to study the inscription, believed that it was a decree of the city of Athens in honour of Hadrian, it was L. Robert who correctly identified it with a decree of the city in Asia Minor issued in Athens. ${ }^{27}$ New fragments and a detailed study of the

24 F. Millar, The Emperor in the Roman World (London 1992), 394-410; M.T. Boatwright, Hadrian and the Cities of the Roman Empire (Princeton 2003), 37.

25 F. Grelle, L'Autonomia cittadina fra Traiano e Adriano (Naples 1972), 65 ff., 116: 'l'oratio de Italicensibus postula quindi una sostanziale analogia fra la situazione dei municipia e quella delle civitates peregrinorum (...) nel rispetto formale della loro libertà.' This analogy may be even truer in the case of the municipia antiqua.

26 Gell. NA 16.13.4: mirarique se ostendit. W. Williams, 'Individuality in the imperial constitutions: Hadrian and the Antonines', Journal of Roman Studies 66 (1977), 69-74. In some rescripts and letters Hadrian clearly demonstrated anger and emotion on the matter in question.

27 P. Graindor, 'Études épigraphiques sur Athènes à l'époque impériale', Revue des Études Grecques 31 (1918), 227-237; L. Robert, Bulletin Épigraphique (1966), no. 144; D.J. Geagan, 
decree of Thyatira, ${ }^{28}$ which is similar in nature, have contributed to a better understanding of the monument. Graindor, however, believing that it was an Athenian decree, proposed a reconstruction for several lines of the fragment edited as IG II ${ }^{2} 1075$ which is still valid. It reads as follows:

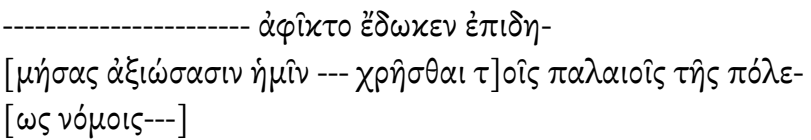

... [after] his arrival, and during his sojourn, he granted those who had so requested the right to use the ancient laws of their city.

For Graindor, this fragment had to be related to the Athenian constitutional reform sponsored by Hadrian. ${ }^{29}$ But since the decree was not Athenian but pertained to the city of Synnada, it can be deduced that the Emperor had also granted the city the right to 'use its ancient laws', just as he intended the Italicans to continue to do. Nonetheless, his involvement in traditional local laws was not limited to ratifying their effectiveness.

Thanks to different pieces of epigraphic evidence, we now know that the Emperor assumed the role of legislator, nomothetes, in some cities including Cyrene, Megara, Sparta and, of course, Athens. Unfortunately for us, in the first three cases nothing more is known of this initiative except that the Emperor was attributed the title of nomothetes on the public monuments of those cities. ${ }^{30}$ Yet, we have some further non-epigraphic evidence in the case of Athens.

The late chronicles tell us how Hadrian, at the request of the Athenians themselves, 'modelled the laws of the city on those of Draco, Solon and others. ${ }^{31}$ Beyond the slight differences between the chronicles, the explicit inten-

'Hadrian and the Athenian Dionysiac technitai', Transactions and Proceedings of the American Philological Association 103 (1972), 158-16o; SEG 30 (1983), 89.

28 D. Peppas-Delmousou and S. Follet, 'Le décret de Thyatire sur les bienfaits d'Hadrien et le Panthéon d'Hadrien à Athènes', Bulletin de Correspondance Hellénique 121 (1997), 291-307; C.P. Jones, 'A decree of Thyatira in Lydia', Chiron 29 (1999), 1-21.

29 Graindor 1918, op. cit. (n. 27), 233-235; P. Graindor, Athènes sous Hadrien (Cairo 1934), 3032 .

30 Cyrene: SEG 17,809; Megara: IG viI 70-72; Boatwright 2003, op. cit. (n. 24), 91-92; Sparta: I.E. Petrocheilos, 'An unpublished inscription from Kythera', The Annual of the British School at Athens 83 (1988), 359-362.

31 Euseb. Chron. ed. A. Schöne II p. 166; Hieron, ab Abr. 2138; Sync., 659, 9. Graindor 1934, op. cit. (n. 29), 30. 
tion of recouping the ancient laws of the city to construct a new political and legal order is quite remarkable. However, the real content of Hadrian's legislative and constitutional reform in Athens is difficult to pinpoint. With more or less justification, it has been credited with the creation of a new urban tribe, the rearranging of the political calendar, the restoration of the Council of Five Hundred, the enactment of the law on debtors, the reorganisation of the opisthodomos, etc. It can also be safely said that the regulation of the exporting of Athenian olive oil formed part of the new Hadrianic laws inspired by ancient traditions. $^{32}$

There are two reasons justifying the soundness of this last assumption. The first is the heading of the inscription which contains the Oil Law as it was published in the Roman Agora of Athens. The heading, although somewhat difficult to interpret, leaves no doubt as to its consideration as part of Hadrian's law. ${ }^{33}$ If the attribution of this law to the Emperor is indisputable, his desire to present it as an example of his intention to reinstate the ancient laws of the city is supported by a singular bit of information conveyed by Plutarch. The biographer had attributed to Solon the general ban on exporting agricultural produce with a view to ensuring the adequate provisioning of the city. Notwithstanding this, Solon would have authorised oil exports, which is precisely the issue regulated in Hadrian's Oil Law. ${ }^{34}$ Thus, the Emperor is yet again seen to have respected the use of Athens' own laws and customs, suis moribus legibusque uti, while intervening directly in the political, constitutional and legislative framework of a free city. His legal and constitutional reforms were based on his power as Roman emperor but, at the same time, were presented as a recovery of the traditional laws of a free Greek city. For all this reasons he enacted them as an Athenian nomothetes, equating himself with Draco and Solon and avoiding a direct intervention which could recall the unfortunate precedent of Sulla. ${ }^{35}$

This combination of two attitudes seemingly at odds with one another, i.e. respect for the city's ancient laws and their restoration and the Emperor's decisive involvement in its affairs as the supreme authority of the Empire, is clear from the content of the law itself. It did not only mean that the regulation of oil sales and exports was a way of fleshing out a reputedly Solonian law. In the

\footnotetext{
32 S. Follet, Athènes au IIe et au IIIe siècle (Paris 1976), 116-125.

33 IG II ${ }^{2}$ 110o. The abbreviations appearing in the first line should be developed as $\mathrm{K} \varepsilon(\varphi \dot{\alpha} \lambda \alpha 1 \alpha)$

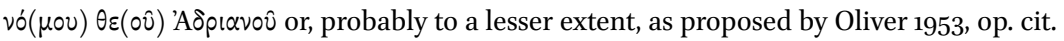

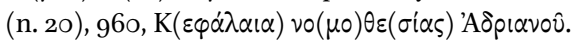

34 Plut., Sol. 24; D. Flach, 'Solons volkswirtschaftliche Reformen', Rivista Storica dell'Antichità 3 (1973), 13-27.

35 Paus. 1.20.7; D.J. Geagan, The Athenian Constitution after Sulla, Hesperia: Supplement XII (Princeton 1967).
} 
Athenian Oil Law, the city's political institutions appear to be in full administrative, political and legal control. The elaionai and the Herald of the Areopagus were tasked with handling Athenian oil production and export declarations. And for their part, the Council of Five Hundred and the Athenian People, the city's assembly, were reaffirmed as the institutions responsible for legal procedures. These procedures had to be assigned to one or other body depending on the greater or lesser magnitude of possible frauds. If, as is usually held, the civic institutions, and particularly the assemblies of the Greek cities, were gradually undermined during the imperial period, a reading of the Oil Law clearly shows that they were fully in charge and supported by the imperial power itself. ${ }^{36}$ There is, however, a new element in this law which obliges us to rethink the limits of an apparently enhanced civic autonomy.

Firstly, the Oil Law established that if the fraudster who was trying to export a larger amount of oil than permitted had already left Athens when his fraud was discovered, the people should submit complaints to the city of origin of the shipping agent and to the Emperor. ${ }^{37}$ Moreover, it decreed that appeals against judgements handed down by the Council of Five Hundred and the Athenian Assembly could be lodged with both the governor of the province, despite the fact that Athens was a free city, and the Emperor himself. ${ }^{38}$

To all of this must be added that the model for ensuring a plentiful supply of oil in Athens was inspired by Roman, rather than Greek, practices of market regulation..$^{39}$ The only conclusion that can be drawn from this is to admit that the recuperation and revitalising of local laws was being carried out in a higher legislative framework which, born from the very existence of the Empire, tended to harmonise local laws, without this necessarily meaning that they were eroded in the process. And the driving force behind this transformation was none other than the Emperor himself.

Hadrian's modus operandi seems clear enough: steps were taken to review local laws which, without being revoked, were amended or corrected to adapt them to the rules and principles prevailing in the Empire. The emperor emerged as the universal source of law and the ultimate judicial authority for appeal against sentences of any civic court. The new Athenian legal code,

$36 \quad$ J. Fournier, Entre tutelle romaine et autonomie civique. L'administration judiciaire dans les provincies hellénophones de l'Empire romain (129 av.J.C.-235 apr.J.C.) (Paris 2010), 159-161.

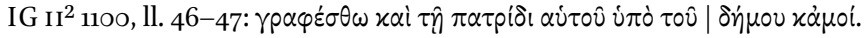

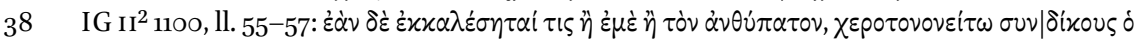
$\delta \hat{\eta} \mu \circ \varsigma$. J.H. Oliver, 'Hadrian's reform of the appeal procedure in Greece', Hesperia 39 (1970), 332-336; Fournier 2010, op. cit. (n. 36), 520-524.

39 K. Harter-Uibopuu, 'Hadrian and the Athenian oil law', in R. Alston and O. van Nijf (eds.), Feeding the Ancient Greek City (Leuven 2008), 137-139. 
although inspired by the ancient laws of Draco and Solon, included the emperor as the supreme judge and the universal court of appeal for the empire, listening to cases judged by local councils and assemblies. The aim was thus to ensure legal uniformity on the basis of the diversity of traditions, thus reconciling apparently conflicting principles.

One of the most interesting extant letters sent by the imperial chancellery to the city of Delphi in AD125 addresses many issues relating to the Delphic Amphictyony: the reform of the council, the organisation of the games, the use of sacred land, etc. ${ }^{40}$ At some point, Hadrian makes it clear that Claudius Timocrates, an agent of his, is reviewing and organising the Amphictyonic decrees, about which he has the following to say: ${ }^{41}$

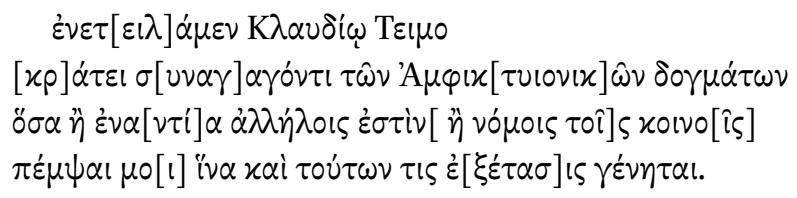

I have ordered Claudius Timocrates, who is collecting the Amphictyonic decrees, to send to me those decrees which are in conflict with one another or with the common laws, in order that an investigation also of these may be made.

This testimony is crucial to understanding the process of political and legal unification in the Empire. Firstly, Hadrian enjoyed the prerogative to intervene in the internal affairs of the Amphictyony and to review its rules and decrees. In this connection, he did not act any differently than in other Greek cities where he was hailed as legislator, nomothetes. Secondly, it is obvious that the Emperor did not intend to abolish the Amphictyony's legal and political structure, repealing its traditional laws and substituting them with new ones. Quite to the contrary, his involvement in the Amphictyonic decrees had a dual objective: to preserve them by means of a process of ordination, standardisation and resolving incompatibilities and to bring them into line with what he called 'the common laws'. This does not seem to be any different from what he planned to do, or was already doing, in Athens and other Greek cities.

40 CID IV 152; J.M. Cortés-Copete, 'El fracaso del primer proyecto panhelénico de Adriano', Dialogues d'Historie Ancienne 25 (1999), 91-112.

41 CID IV 152, II, 37-40; J.H. Oliver, Greek Constitutions of Early Roman Emperors (Philadelphia 1989), no. 75 . 
The procedures followed by Hadrian in the cases analysed here could be described as ones aimed at generally reviewing the laws of a city or the Amphictyony. These were doubtless exceptional circumstances in which to undertake the harmonisation of traditional laws with those 'common laws' invoked by the Emperor himself. It must be noted, however, that these procedures had their limits. A systematic review of the constitutions of all the Greek poleis and koina to bring them into line with Roman legal practices seems an incredible undertaking for an emperor at the beginning of the second century. Nevertheless, Hadrian had another instrument to carry out that harmonisation in specific cases and whenever necessary: the imperial chancellery.

As is well known, the number of letters that Hadrian sent to Greek cities and institutions doubles that of all the extant letters of his predecessors. It is my belief that the abundance of Hadrianic letters is the result of the Emperor's desire for a rapprochement with his subjects and to intervene politically and legally in Greek cities and leagues. ${ }^{42}$ Through these letters, he not only granted privileges and honours but also resolved many new legal and political quandaries deriving from the integration of these cities in the Empire. Despite the fact that the issues addressed are specific, a grammar tending to legal harmonisation can be recognised in imperial decisions. The Emperor's reaction was always to adapt local laws and traditions to 'the common laws'. A few examples may help to clarify this procedure.

From Piraeus there are fragments of a letter of Hadrian's which have been traditionally interpreted as pertaining to both the regulation of the sale of fish in Eleusis and part of the new Athenian constitution dictated by him. ${ }^{43}$ On a previous occasion, I have had the chance to review this interpretation of the letter, before reaching different conclusions. ${ }^{44}$ The document's epistolary format rules out the possibility that it might have formed part of the Athenian constitution, although the provisions established for its obligatory publication

42 J.M. Cortés-Copete, 'Governing by dispatching letters: the Hadrianic chancellery', in C. Rosillo-López (ed.), Political Communication in the Roman World (Leiden 2017), 107136; T. Carboni, La parola scritta al servizio dell'imperatore e dell'Impero (Bonn 2017), 103128.

43 A. Wilhelm, 'Inschriften aus Erythrai und Chios', Jahreshefte des österreichischen archäologischen Instituts in Wien 12 (1909), 146-148; Graindor 1934, op. cit. (n. 29), 127-129; Oliver 1989, op. cit. (n. 41), no. 77 .

44 J.M. Cortés-Copete, 'Adriano y la regulación de los mercados cívicos: una nueva lectura de IG II ${ }^{2} 1103$ ', Habis 46 (2015), 239-261. 
lend it a special normative value. ${ }^{45}$ Moreover, I believe that, according to the hypothesis put forward by Kirchner, ${ }^{46}$ this imperial letter had nothing to do with the regulation of the sale of fish in Eleusis, but with banning the activities of middlemen who, through successive purchase and sale transactions, speculatively forced up the price of imported products. In this regard, I have attempted to demonstrate how the Athenian letter contained no more than

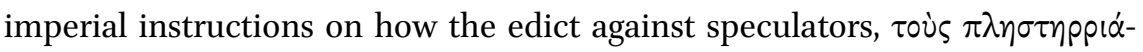

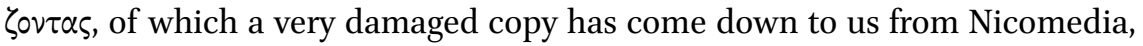
should be enforced. ${ }^{47}$ The proposed restoration of lines 6 and 8 reads as follows:

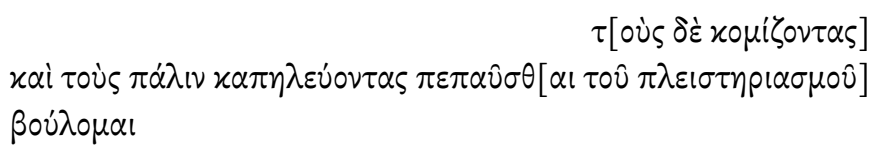

It is my desire that importers and those who again resell (the merchandise) abstain from driving up prices.

So this may provide us with a connection between one of those common laws, the edict of Nicomedia, and its enforcement in a specific city, Athens. This enforcement would have been achieved by means of an imperial letter in which the specific jurisdictions of the Athenian institutions, the Herald and the Council of the Areopagus, were also established, as in the edict of Nicomedia. ${ }^{48}$

This procedure by which the general rules governing particular realities were applied was resorted to on other occasions and in other places. Let us now take a look at a second example that did not affect the life of a city but the Koinon of Macedonia, to which the Emperor sent a letter in AD137. After excluding the formulas of greeting and leave-taking, the letter's text reads as follows: ${ }^{49}$

As you requested, whoever at end of his term of office proposes others as candidates should inform those whose names are to be put forward with

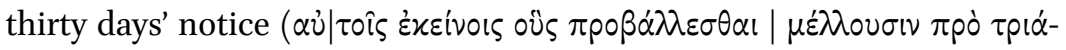

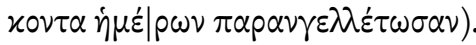

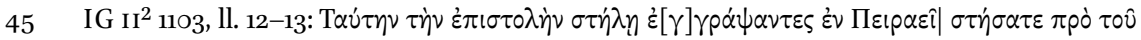

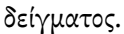

$46 \quad \mathrm{IG} \mathrm{II}^{2}$, 1103. F.F. Abbott and A.Ch. Johnson, Municipal Administration in the Roman Empire (Princeton 1926), 413-414.

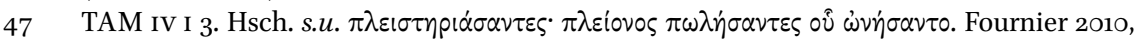
op. cit. (n. 36), $5^{20-}-524$.

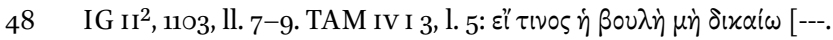

49 SEG 37, 593, II. 8-13.
} 
The letter provides a good example of the thesis that I am defending here. Possibly, the post to which Hadrian is referring is that of politarcha, a magistrate inherent to Macedonia before the Roman domination, but which, as can be read at the bottom of this same letter, was still in place in the imperial period. ${ }^{50}$ The politarchai were undoubtedly the most senior magistrates in the Koinon of Macedonia. The question put to the Emperor had to do with the procedure for choosing successors to the different posts, which was called nominatio in Latin and probolé in Greek. ${ }^{51}$ Without explaining the reasons behind his decision, he established a thirty-day period between the nominatio and the taking up of office. I think that the reason could have been to establish, according to Roman legislative tradition, a period during which the candidates could exercise their right of appeal to the governor and even to the Emperor himself. ${ }^{52}$ As a matter of fact, in Oinoanda the procedure, probolé, to nominate the agonothet $a$ among the bouleutai was enacted 'according to the laws concerning the elections', probably Roman laws rather than local ones. ${ }^{53}$ The functioning of the Koinon of Macedonia would have been thus adapted to another of those Roman rules that tended to harmonise the Empire's legal system, but without supressing the peculiarities of each one of the bodies, cities and leagues comprising it.

One of the most significant processes in the historical evolution of the Roman Empire was that by which the emperors ended up becoming its exclusive lawmakers. This tendency towards monopolising the law reached an important milestone during Hadrian's reign. ${ }^{54}$ This meant that, as regards his provincial

$50 \quad$ F. Gschnitzer, s.v., $R E$ Suppl. XIII (1973), 43-50; F. Papazoglou, Les villes de Macédoine à l'époque romaine (Paris 1988), 50-51.

$51 \quad$ M. Wörrle, Stadt und Fest im kaiserzeitlichen Kleinasien (Munich 1988), 14 (ll. 89-92), 86-

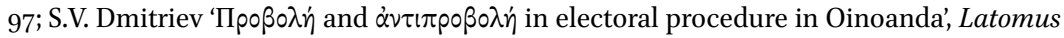

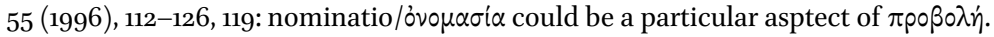

C.J. x 32.2: quifuerit nominatus per officialem publicum perferre curent, habituro appellandi, si voluerit, atque agendi facultatem apud praesidem causam suam iure consueto. A subsequent case, in which recourse was had to the apellatio, had to do with the legal vicissitudes of Aristides: V. Marotta, 'Le strutture dell'amministrazione provinciale nel quarto libro dei Discorsi Sacri', in P. Desideri and F. Fontanella (eds.), Elio Aristide e la legitimazione greca dell'impero di Roma (Bologna 2013), 147-184.

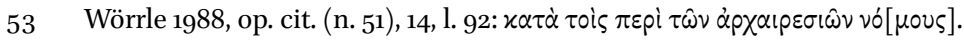

54 D' Ors 1965, op. cit. (n. 23); T. Honoré, Emperors and Lawyers (Oxford 1994), 12-16. 
subjects, he had the undisputed capacity to intervene, reform, adapt and enact new laws for the cities and koina in the provinces. Furthermore, he became the court of last resort or, in the words of Tuori, he was seen 'as the ideal judge' ${ }^{55}$

The entire process by which Hadrian became the driving force behind the enactment and enforcement of laws is eloquently described in three letters sent to the Synod of Dionysiac Artists, dated AD134 and engraved on a large stele set up in Alexandria Troas. ${ }^{56}$ After the customary greeting, Hadrian starts by saying (ll. $8-9)$ :

I ordain that all the contests be celebrated; and a city is not to be permitted to apply to other expenditures the revenues of a contest that are managed according to law or decree or contractual agreements ( $\varkappa \alpha \tau \dot{\alpha}$ vó $\mu \circ v$ $\grave{\eta} \psi \dot{\eta} \varphi(\sigma \mid \mu \alpha$ ทे $\delta(\alpha \theta \dot{\eta} \kappa \alpha \varsigma) .57$

This extract is extremely valuable for understanding the legal harmonisation process promoted by Hadrian. He regarded the Greek games as an essential part of the civilisation that Rome should defend and decided to protect them against any threat. ${ }^{58}$ As is well known, the main danger facing the games was the misappropriation of funds earmarked for their organisation and celebration. For this reason, in the letter addressed to the synodos of the technitas the Emperor proclaims himself a champion of the laws and civic decrees under which they are created and organised, as well as of the private institutions, diathekai, testaments and foundations that contribute to their functioning and funding. But that desire to protect the invaluable asset symbolised by the agones had an aftereffect that was just as important as the main objective. The protection established by the emperor over games, and over the local laws and decrees that ruled them was so powerful that the institutions that had enacted them lost the capacity to modify them without the Hadrian's consent. (ll. 1213):

55 Tuori 2016, op. cit. (n. 5), 196-240.

56 G. Petzl and E. Schwertheim, Hadrian und die Dionysischen Künstler (Bonn 2006); SEG 56, 1359; C.P. Jones, 'Three new letters of the emperor Hadrian', Zeitschrift für Papyrologie und Epigraphik 161 (2007), 145-156.

57 Translation by W.J. Slater, 'Hadrian's letters to the athletes and Dionysiac Artists concerning arrangements for the circuit of games', Journal of Roman Archaeology 21 (2008), 610-62o.

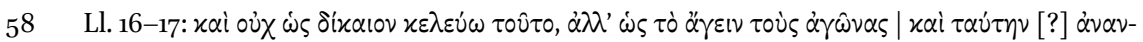
x $10 \mathrm{v} \gamma \varepsilon i v \varepsilon \sigma \theta \alpha$, 'and I ordain this not only because it is fair but because holding the games and this [?] is something that is necessary'; Z. Newby, Greek Athletics in the Roman World (Oxford 2009). 


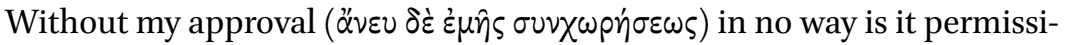
ble to expend for any such purpose these funds that are set aside for the games.

Throughout these pages, I have attempted to show that in his Roman Oration Aristides managed to reflect the profound changes occurring during Hadrian's reign in both local and Roman legislation and laws governing the inhabitants of the Empire. As claimed by the Emperor in his letter to Delphi in AD125, it had been his idea to establish a set of common laws that served as a benchmark for the legal harmonisation of the plethora of constitutions, statutes and regulations that were in force in each place. The result was, in Aristides words, that 'all actions everywhere are full of justice and respect, and the reward of virtue escapes no one. ${ }^{59}$ Through his endeavours as nomothetes of several Greek cities and, especially, the new and intense activity of his chancellery, Hadrian appears as a central figure in the legal harmonisation of the Empire, creating a more just world, 'such indeed is Olympian Zeus' empire within.'60 It is not necessary to insist that in the Greek East, in the year AD 143, Hadrian's Olympian nature was obvious for everyone. ${ }^{61}$

In all of his letters, Hadrian uses the first person singular to embody authority. The pronouns I, me, to me and mine- $\dot{\varepsilon} \gamma \dot{\omega}, \mu \varepsilon, \mu \circ, \dot{\varepsilon} \mu \hat{\eta} \varsigma$-are also omnipresent, as are the verbs I want, I ordain, I will call, etc.— $\beta 0^{\prime} \lambda \circ \mu \alpha \mathrm{l}, x \varepsilon \lambda \varepsilon \dot{v} \omega, x \alpha \lambda \varepsilon \dot{\varepsilon} \sigma \omega$. The Emperor was becoming the sole guarantor of legal certainty and safety in the Empire. His mission as the protector of the Roman world and the defender of concord amongst his subjects increased, by leaps and bounds, his absolute power as the only source and guarantor of law in the Empire. Under Hadrian, the idea that the will of the emperor had the force of law and that the emperor decided what the law was had already been firmly established in the writings of jurists. ${ }^{62}$ At any rate, the result was not the legal unification of the Empire under one sole law, but the reinforcement of local laws insofar as they were adapted to a number of common principles firmly inspired by the idea of justice. It is thus possible to fully understand Aristides' opinion of the Romans who were

59 Aristid. 26.89. Diké and Aidós are the fundamentals of the political system: Pl. Prot. 320c$322 \mathrm{~d}$.

6o Aristd. 26. 89. Aristides cites an Homeric verse (Od.4.74) but changes the last original word, $\dot{\alpha} v \lambda \dot{\eta}$, 'court', into $\dot{\alpha} p x \dot{\eta}$ 'empire'.

61 M. Galli, 'Theos Hadrianos: le élites delle città greche e il culto dell'imperatore filelleno', in A.D. Rizakis and F. Camia (eds.), Pathways to the Power (Athens 2008), 73-105.

62 Pomp. 1 Enhir (D. 1.2.2.11); Gaius Inst. 1.5; Ulp. Inst. 1 (D. 1.4.1); Honoré 1994, op. cit. (n. 54), 12. 
'assigning common laws for all', which were already being established a century before the Constitutio Antoniniana and greatly surpassed any similar enterprise that might have been attributed to Alexander the Great. 